DOI:10.22337/2587-9618-2019-15-3-77-83

\title{
FORCED VIBRATIONS OF ANISOTROPIC ELASTIC SOLIDS SUBJECTED TO AN ACTION OF COMPLICATED LOADS
}

\author{
Elena B. Koreneva ${ }^{1}$, Valery R. Grosman ${ }^{2}$ \\ ${ }^{1}$ Moscow Higher Combined-Arms Command Academy, Moscow, RUSSIA \\ ${ }^{2}$ Moscow State Academy for River Transport, branch of Admiral Makarov State University of Maritime \\ and Inland Shipping, Moscow, RUSSIA
}

\begin{abstract}
The work studies the forced vibrations of anisotropic elastic circular plates caused by dynamic loads uniformly distributed along concentric circumferences and over ring surfaces. The method of compensating loads (MCL) is used to solve the formulated problems. A new technique is used to construct basic and compensating solutions. The Nielsen's equation is taken into consideration. The solutions are obtained in closed form in terms of Bessel functions. Formulae of addition of cylindrical functions are used.
\end{abstract}

Key words: anisotropy, circular plates, forced vibrations, Bessel functions

\section{ВЫНУЖДЕННЫЕ КОЛЕБАНИЯ АНИЗОТРОПНЫХ УПРУГИХ ТЕЛ ПРИ СЛОЖНЫХ НАГРУЗКАХ}

\author{
Е.Б. Коренева ${ }^{1}$, В.Р. Гросман ${ }^{2}$ \\ ${ }^{1}$ Московское высшее общевойсковое командное орденов Жукова, Ленина и Октябрьской Революции \\ Краснознаменное училище, г. Москва, РОССИЯ \\ ${ }^{2}$ Московская государственная академия водного транспорта - филиал Государственного университета \\ морского и речного флота имени адмирала С.О. Макарова, г. Москва, РОССИЯ
}

\begin{abstract}
Аннотация: В работе изучаются вынужденные колебания анизотропных упругих круглых пластин, вызванные действием нагрузок, распределенных вдоль концентрических окружностей и по площадям колец. Для решения поставленных задач используется метод компенсирующих нагрузок (МКН). Для построения базовых решений - основного и компенсирующего, используется новый прием, берется в рассмотрение уравнение Нильсена. Решения получены в замкнутом виде и выражены в функциях Бесселя. Используются формулы сложения цилиндрических функций.
\end{abstract}

Ключевые слова: анизотропия, круглые пластины, вынужденные колебания, функции Бесселя

\section{INTRODUCTION}

In literature, for example in [1], the questions concerning analytical methods application to the solution of problems of statics and oscillations of elastic isotropic circular plates are covered. However, if the mentioned constructions are made from anisotropic material the application of analytical methods in the same ways as for isotropic ones causes considerable difficulties. For the cases of isotropic plates the resolving differential equation of the fourth order with variable coefficients is decomposed into two conjugate differential equations of the second order. The solutions are expressed in terms of Bessel func- tions. When solving the problems of anisotropic plates, the corresponding differential equation of the fourth order with variable coefficients does not decompose into two conjugate equations for any parameter values. This work applies the new approach for solving certain dynamic problems. Nielsen's equation is used. First the similar approach was proposed for consideration of static problems of anisotropic circular plates resting on Winkler's foundation [2].

Let us assume that the plate material has cylindrical anisotropy and is orthotropic. The construction under study is subjected to an action of dynamic loads uniformly distributed along the lengths of concentric circles and over ring surfaces. 


\section{THE RESOLVING EQUATION}

We present a differential equation describing the natural axisymmetric oscillation of a circular orthotropic plate [3], [4]:

$$
\begin{gathered}
r^{4} \frac{\partial^{4} w}{\partial r^{4}}+2 r^{3} \frac{\partial^{3} w}{\partial r^{3}}-n^{2} r^{2} \frac{\partial^{2} w}{\partial r^{2}}+n^{2} r \frac{\partial w}{\partial r}+ \\
+\frac{\gamma h}{g n_{2} D} \frac{\partial^{2} w}{\partial t^{2}}=0
\end{gathered}
$$

where $D-$ cylindrical rigidity,

$$
\begin{aligned}
E_{r}=\frac{E}{n_{1}}, E_{\theta}=E n_{2}, \sigma_{r}=\frac{\sigma}{n^{2}}, \sigma_{\theta}=\sigma, & \\
& n^{2}=n_{1} n_{2} .
\end{aligned}
$$

When considering axisymmetric vibrations the solution of the equation (1) has the form:

$$
w=\sum_{S=0}^{\infty}\left(A_{S} \cos p_{S} t+B_{S} \sin p_{S} t\right) W_{S},
$$

here $p_{S}$ - circular frequency of natural vibrations, $W_{S}$ - a function of only the coordinate $r$, constants $A_{S}$ and $B_{S}$ are determined from initial conditions, $S$ is the number of nodal diameters. As it was mentioned above, the studies have shown that for a plate made from orthotropic material, the initial fourth-order differential equation for any parameter values does not decay into two mutually adjoint second order equations as in the case for isotropic plates. Therefore, here to obtain an accurate analytical solution in terms of Bessel functions and for the application of the method of compensating loads (MCL) [2], [3], another technique was used. Nielsen's equation was introduced into consideration. As a result the following solutions were obtained.

When the parameter $\mu=0$, the general solution of the differential equation (2) has the form:

$$
\begin{aligned}
W_{S}=C_{1} J_{0}(b r) & +C_{2} Y_{0}(b r)+C_{3} I_{0}(b r)+ \\
& +C_{4} K_{0}(b r) ;
\end{aligned}
$$

for the parameter values $\mu= \pm 2$ the general solution of (2) is determined from the expression:

$$
\begin{aligned}
W_{S}=B_{1} u_{\mu}(b r) & +B_{2} v_{\mu}(b r)+B_{3} f_{\mu}(b r)+ \\
& +B_{4} g_{\mu}(b r),
\end{aligned}
$$

where

$$
b=\sqrt[4]{\frac{\gamma h}{g n_{2} D} p_{S}^{2}} .
$$

\section{THE METHOD OF COMPENSATING LOADS}

In [3], forced oscillations of a circular orthotropic plate subjected to an action of a concentrated force in the center were studied. MCL was used for this purpose.

Below we will consider the forced vibrations of such plates under the action of much more complicated loads distributed along circumferences that do not coincide with the contour and loads distributed over areas of rings. MCL will also be used to build the solution. We introduce a dimensionless coordinate $x=b r$. Let us assume that the plate under study is clamped along the contour.

First we will examine an action on the plate of the concentrated force $P \sin p t$ applied in the center.

Then the basic solution, which should contain a feature of the type of concentrated force, should be written in the form:

$$
W_{0}=C_{0} Y_{0}(x)+D_{0} K_{0}(x) .
$$

The compensating solution is determined by the formula:

$$
W_{k}=A_{0} J_{0}(x)+B_{0} I_{0}(x) .
$$


In the expression (5) the functions $Y_{0}(x)$ and $K_{0}(x)$ are tend to infinity as $\ln x$. On the basis of the theory of Bessel functions we put

$$
D_{0}=\frac{2}{\pi} C_{0}
$$

The coefficient $C_{0}$ is determined from equilibrium conditions. Let us draw a circle of small radius $x / b$ with the center in the point $x=0$. We calculate the sum of the transverse forces acting on the circle of the mentioned radius and passage to the limit when $x \rightarrow 0$.

Performing all calculations [3], we get:

$$
C_{0}=-\frac{P}{8 D n_{2} b^{2}}
$$

As a result, (5) will take the form:

$$
W_{0}=-\frac{P}{8 D n_{2} b^{2}}\left[Y_{0}(x)+\frac{2}{\pi} K_{0}(x)\right]
$$

Summing up the basic and the compensating solutions, we define:

$$
\begin{aligned}
W=A_{0} & J_{0}(x)+B_{0} I_{0}(x)-\frac{P}{8 D n_{2} b^{2}} \times \\
\times & {\left[Y_{0}(x)+\frac{2}{\pi} K_{0}(x)\right] . }
\end{aligned}
$$

The constants $A_{0}$ and $B_{0}$ are determined from boundary conditions. We set in our case that when $x=\beta$ the outer boundary is clamped. When

$$
x=\beta, w=0, \frac{d w}{d x}=0 .
$$

As a result of a number of transformations and using certain dependencies from Bessel's functions theory, we obtain the following expressions for $A_{0}$ and $B_{0}$ :

$$
\begin{gathered}
A_{0}=\frac{P}{8 D_{0} n_{2} b^{2}} \times \\
\times \frac{I_{1}(\beta) Y_{0}(\beta)+I_{0}(\beta) Y_{1}(\beta)+\frac{2}{\pi \beta}}{J_{0}(\beta) I_{1}(\beta)+J_{1}(\beta) I_{0}(\beta)}, \\
B_{0}=\frac{P}{8 D_{0} n_{2} b^{2}} \times \\
\times \frac{\frac{2}{\pi}\left[J_{1}(\beta) K_{0}(\beta)-J_{0}(\beta) K_{1}(\beta)\right]+\frac{2}{\pi \beta}}{J_{0}(\beta) I_{1}(\beta)+J_{1}(\beta) I_{0}(\beta)} .
\end{gathered}
$$

In the case of another boundary conditions on the contour, the basic solutions will remain unchanged and the general form of the compensating solution will also remain. Due to the change of boundary conditions only the formulae for determining of the constants $A_{0}$ and $B_{0}$ will be different.

\section{THE CALCULATION OF THE EFFECT OF LOAD DISTRIBUTED ALONG CIRCLES}

We proceed to the study of the problem of forced oscillation of an anisotropic circular plate clamped along the contour caused by a load uniformly distributed around the circumference concentric with the contour and having a radius $a_{1}$. Denote the amplitude of the load $q \sin p t$ as $q$. As it was shown above, we present the form of oscillation as the sum of the basic solution $W_{0}$ and the compensating solution $W_{k}$.

First we will define the basic solution. For this aim, mentally divide the loads acting along the circumference on the number of elementary loads. Next we sum-up the result of these loads. Take on the circle, on which the load is applied, a point with the coordinates $\left(a_{1}, x\right)$. Elementary load acting on the section of arc with the length $a_{1} d \theta$ is determined by the expression

$$
\frac{q a_{1} d \theta}{b} .
$$


Find the deflection in the point with the reduced coordinates $x, \varphi$. To do this we use the formula (8). Substituting instead $P$ the expression (11) and instead $x$ the distance from the point of the elementary force application to the considered point of the plate, which is as follows:

$$
z=\sqrt{a_{1}^{2}+x^{2}-2 a_{1} x \cos (\theta-\varphi)} .
$$

We make integration. Calculation of integrals should use the formulae of cylindrical functions addition, which in the studied case are of the form:

when $x \leq a_{1}$

$$
\begin{aligned}
& Y_{0}\left(\sqrt{a_{1}^{2}+x^{2}-2 a_{1} x \cos (\theta-\varphi)}\right)= \\
& =2 \sum_{0}^{\infty} J_{n}(x) Y_{n}\left(a_{1}\right) \cos n(\theta-\varphi), \\
& K_{0}\left(\sqrt{a_{1}^{2}+x^{2}-2 a_{1} x \cos (\theta-\varphi)}\right)= \\
& =2 \sum_{0}^{\infty} I_{n}(x) K_{n}\left(a_{1}\right) \cos n(\theta-\varphi),
\end{aligned}
$$

when $x \geq a_{1}$

$$
\begin{aligned}
& Y_{0}\left(\sqrt{a_{1}^{2}+x^{2}-2 a_{1} x \cos (\theta-\varphi)}\right)= \\
& =2 \sum_{0}^{\infty} J_{n}\left(a_{1}\right) Y_{n}(x) \cos n(\theta-\varphi), \\
& K_{0}\left(\sqrt{a_{1}^{2}+x^{2}-2 a_{1} x \cos (\theta-\varphi)}\right)= \\
& =2 \sum_{0}^{\infty} I_{n}\left(a_{1}\right) K_{n}(x) \cos n(\theta-\varphi) .
\end{aligned}
$$

In this formulae the sign ' means that for $n=0$ an additional factor $1 / 2$ is introduced. Write down:

$$
\begin{gathered}
w_{0}=-\int_{0}^{2 \pi} \frac{q a_{1}}{8 D n_{2} b^{3}}\left[Y_{0}(z)+\frac{2}{\pi} K_{0}(z)\right] d \theta= \\
=-\frac{q a_{1}}{8 D n_{1} b^{3}} \times \\
\times\left[\int_{0}^{2 \pi} Y_{0}\left(\sqrt{a_{1}^{2}+x^{2}-2 a_{1} x \cos (\theta-\varphi)}\right) d \theta+\right. \\
\left.+\frac{2}{\pi} \int_{0}^{2 \pi} K_{0}\left(\sqrt{a_{1}^{2}+x^{2}-2 a_{1} x \cos (\theta-\varphi)}\right) d \theta\right]
\end{gathered}
$$

Substituting (12), (13), (14) and (15) in (16) and performing the integration; we note that all the series members when $n \geq 0$ at integration give zero. Therefore the solution will include only the result of integration of the zero term.

We have when $x \leq a_{1}$

$$
\begin{gathered}
w_{0}=-\frac{\pi q a_{1}}{4 D n_{2} b^{3}} \times \\
\times\left[J_{0}(x) Y_{0}\left(a_{1}\right)+\frac{2}{\pi} I_{0}(x) K_{0}\left(a_{1}\right)\right]
\end{gathered}
$$

when $x>a_{1}$

$$
\begin{gathered}
w_{0}=-\frac{\pi q a_{1}}{4 D n_{2} b^{3}} \times \\
\times\left[J_{0}\left(a_{1}\right) Y_{0}(x)+\frac{2}{\pi} I_{0}\left(a_{1}\right) K_{0}(x)\right] .
\end{gathered}
$$

We receive the solution of the problem adding to the basic solution the compensating one:

$$
w=w_{0}+A_{0} J_{0}(x)+B_{0} I_{0}(x)
$$

The coefficients $A_{0}$ and $B_{0}$ are determined from the boundary conditions. Here it was assumed that the outer contour of the plate when $x=\beta$ is clamped. Determining the mentioned coefficients $A_{0}$ and $B_{0}$ and using the expression for Wronskian, we get: 


$$
\begin{aligned}
& A_{0}=\frac{\pi q a_{1}}{4 D n_{2} b^{3}} \frac{J_{0}\left(a_{1}\right)\left[I_{1}(\beta) Y_{0}(\beta)+I_{0}(\beta) Y_{1}(\beta)\right]+\frac{2}{\pi \beta} I_{0}\left(a_{1}\right)}{I_{0}(\beta) J_{1}(\beta)+I_{1}(\beta) J_{0}(\beta)} \\
& B_{0}=\frac{\pi q a_{1}}{4 D n_{2} b^{3}} \frac{\frac{1}{\beta} J_{0}\left(a_{1}\right)+I_{0}\left(a_{1}\right)\left[I_{1}(\beta) K_{0}(\beta)-J_{0}(\beta) K_{1}(\beta)\right]}{I_{0}(\beta) J_{1}(\beta)+I_{1}(\beta) J_{0}(\beta)}
\end{aligned}
$$

For the cases of other boundary conditions only the equations for determining the constants $A_{0}$ and $B_{0}$ in the corresponding compensating solution will change.

\section{THE LOADS DISTRIBUTED OVER RING SURFACES}

We proceed to the study of forced oscillations caused by the load $q_{1} \sin p t$, uniformly distributed over the area of the ring with the inner radius $a_{2}$ and the outer one $a_{3}\left(a_{2}<a_{1}<a_{3}\right)$.

Let's define the basic solution. To do this the specified ring is divided into elementary concentric rings. The reduced inner radius of the elementary ring is denote by $a_{1}$, the outer one as $a_{1}+d a_{1}$. The load acting on the unit length of the ring is equal to

$$
q=q_{1} \frac{d a_{1}}{b}
$$

The solution corresponding to the action of the elementary load is determined by the expressions (17) and (18) in which $q$ should be replaced by

$$
q_{1} \frac{d a_{1}}{b}
$$

Integrating these expressions in the range $a_{1}$ from $a_{2}$ to $a_{3}$, we obtain a solution of the problem under study. If the cross-section is in the inner circle when $x \leq a_{2}$ which is free from external load, the expression (17) is to be integrat$\mathrm{ed}$, that is

$$
\begin{gathered}
w_{0}=-\frac{\pi q_{1}}{4 D b^{4}} \times \\
\times \int_{a_{2}}^{a_{3}}\left[J_{0}(x) Y_{0}\left(a_{1}\right)+\frac{2}{\pi} I_{0}(x) K_{0}\left(a_{1}\right)\right] a_{1} d a_{1} .
\end{gathered}
$$

From the theory of Bessel functions, for example from [1], the following relations are known:

$$
\begin{aligned}
& \frac{d}{d x}\left[x^{n} Y_{n}(x)\right]=x^{n} Y_{n-1}(x), \\
& \frac{d}{d x}\left[x^{n} K_{n}(x)\right]=-x^{n} K_{n-1}(x) .
\end{aligned}
$$

Assuming $n=1$ we get:

$$
\begin{aligned}
& \int x Y_{0}(x) d x=x Y_{1}(x), \\
& \int x K_{0}(x) d x=-x K_{1}(x)
\end{aligned}
$$

Taking into account (25) and (26) the expression for $w_{0}$ when $x \leq a_{2}$ will take the following form:

$$
\begin{aligned}
w_{0}= & -\frac{\pi q_{1}}{4 D n_{2} b^{4}}\left\{\left[a_{3} Y_{1}\left(a_{3}\right)-a_{2} Y_{1}\left(a_{2}\right)\right] J_{0}(x)-\right. \\
& \left.-\frac{2}{\pi}\left[a_{3} K_{1}\left(a_{3}\right)-a_{2} K_{1}\left(a_{2}\right)\right] I_{0}(x)\right\} .
\end{aligned}
$$

When considering a part $x \geq a_{3}$ the expression (18) must be integrated. To do this we should take into account the ratio [1]:

$$
\begin{aligned}
& \frac{d}{d x}\left[x^{n} J_{n}(x)\right]=x^{n} J_{n-1}(x), \\
& \frac{d}{d x}\left[x^{n} I_{n}(x)\right]=x^{n} I_{n-1}(x) ;
\end{aligned}
$$


hence for $n=1$ we get:

$$
\begin{aligned}
& \int x J_{0}(x) d x=x J_{1}(x) \\
& \int x I_{0}(x) d x=x I_{1}(x)
\end{aligned}
$$

Thus when $x \geq a_{3}$ we get:

$$
\begin{aligned}
w_{0}= & -\frac{\pi q_{1}}{4 D n_{2} b^{4}}\left\{\left[a_{3} J_{1}\left(a_{3}\right)-a_{2} J_{1}\left(a_{2}\right)\right] Y_{0}(x)+\right. \\
& \left.+\frac{2}{\pi}\left[a_{3} I_{1}\left(a_{3}\right)-a_{2} I_{1}\left(a_{2}\right)\right] K_{0}(x)\right\} .
\end{aligned}
$$

When considering the area under the load when $a_{2} \leq x \leq a_{3}$ to determine the solution of the problem we should integrate (18) when $a_{2} \leq a_{1} \leq x$ and when $a_{1} \leq x \leq a_{3}$ we should integrate (17), replacing $q$ on

$$
q_{1} \frac{d a_{1}}{b}
$$

as elsewhere. At the same time, using the formulae (25), (26), (30) and (31), we get the following result when $a_{2} \leq x \leq a_{1}$ :

$$
\begin{gathered}
w_{0}=-\frac{\pi q_{1}}{4 D n_{2} b^{4}}\left\{\left[x J_{1}(x)-a_{3} J_{1}\left(a_{2}\right)\right]-\right. \\
-Y_{0}(x)+\frac{2}{\pi}\left[x I_{1}(x)-a_{2} I_{1}\left(a_{2}\right)\right] K_{0}(x)+ \\
+\left[a_{3} Y_{1}\left(a_{3}\right)-x Y_{1}(x)\right] J_{0}(x)- \\
\left.-\frac{2}{\pi}\left[a_{3} K_{1}\left(a_{3}\right)-x K_{1}(x)\right] I_{0}(x)\right\} .
\end{gathered}
$$

By regrouping we obtain:

$$
\begin{aligned}
w_{0}= & -\frac{\pi q_{1}}{4 D n_{2} b^{4}}\left\{x\left[J_{1}(x) Y_{0}(x)-Y_{1}(x) J_{0}(x)\right]+\right. \\
& +\frac{2 x}{\pi}\left[I_{1}(x) K_{0}(x)+I_{0}(x) K_{1}(x)\right]- \\
& -a_{2} J_{1}\left(a_{2}\right) Y_{0}(x)-\frac{2}{\pi} a_{2} I_{1}\left(a_{2}\right) K_{0}(x)+ \\
& \left.+a_{3} Y_{1}\left(a_{3}\right) J_{0}(x)-\frac{2}{\pi} a_{3} K_{1}\left(a_{3}\right) I_{0}(x)\right\} .
\end{aligned}
$$

Using the expression for Wronskian we get:

$$
\begin{gathered}
w_{0}=-\frac{\pi q_{1}}{4 D n_{2} b^{4}}\left[\frac{4}{\pi}-a_{2} J_{1}\left(a_{2}\right) Y_{0}(x)-\right. \\
-\frac{2}{\pi} a_{2} I_{1}\left(a_{2}\right) K_{0}(x)+a_{3} Y_{1}\left(a_{3}\right) J_{0}(x)- \\
\left.-\frac{2}{\pi} a_{3} K_{1}\left(a_{3}\right) I_{0}(x)\right] .
\end{gathered}
$$

Summing the basic and compensating solutions we obtain the expression which is similar to (19) where the constants $A_{0}$ and $B_{0}$ are determined from the boundary conditions.

\section{CONCLUSION}

The present work for the first time receives the exact analytical solutions of the problems of forced vibrations of circular plates which are made from material having cylindrical anisotropy. The constructions under study are subjected to an action of dynamic loads uniformly distributed along the lengths of concentric circumferences and over areas of ring surfaces. Method of compensating loads for determination of the solutions is used. The solutions are obtained in terms of Bessel functions.

\section{REFERENCES}

1. Korenev B.G. Nekotoryye Zadachi Teorii Uprugosti i Teploprovodnosti, Reshayemyye v Besselevykh Funktsiyakh. [Some Problems of the Theory of Elasticity and Heat Conductivity, Solved in Terms of Bessel Functions]. Moscow, Fizmatgiz, 1960, 458 pages (in Russian).

2. Koreneva E.B. Method of Compensating Loads for Solving of Anisotropic Medium Problems // International Journal for Computational Civil and Structural Engineering, 2018, Volume 14, Issue 1, pp. 71-77.

3. Koreneva E.B. Analiticheskiy Metod dlya Resheniya Zadach o Kolebaniyah Anizotropnych Uprugich Tel. [Analytical Method for Solving of Anisotropic Elastic 
Solids Vibration Problems] // Stroitelnaya Mekhanika i Raschet Sooruzheniy, 2018, No. 5, pp. 47-51 (in Russian).

4. Koreneva E.B. Analiticheskoje Modelirovanije Nekotorych Zadach Statiki i Kolebanij Anizotropnych Uprugich Tel. [Analytical Simulation of Certain Statics and Vibration Problems of Anisotropic Solids] // VII International Symposium APCSCE, July, 1-8, 2018, Novosibirsk, pp. 478 (in Russian).

\section{СПИСОК ЛИТЕРАТУРЫ}

1. Коренев Б.Г. Некоторые задачи теории упругости и теплопроводности, решаемые в бесселевых функциях. - М.: Физматгиз, 1960. - 458 с.

2. Коренева Е.Б. Метод компенсирующих нагрузок для решения задач об анизотропных средах. // International Journal for Computational Civil and Structural Engineering, 2018, Volume 14, Issue 1, c. 7177.

3. Коренева Е.Б. Аналитический метод для решения задач о колебаниях анизотропных упругих тел. // Строительная механика и расчет сооружений, 2018, №5, c. 47-51.

4. Коренева Е.Б. Аналитическое моделирование некоторых задач статики и колебаний анизотропных упругих тел. // VII International Symposium APCSCE, July, 1-8, 2018, Novosibirsk, c. 478.

Elena B. Koreneva, Dr.Sc., Professor; Moscow Higher Combined-Arms Command Academy; ul. Golovacheva, 2, 109380, Moscow, Russia; phone: +7(499)175-82-45;

E-mail: elena.koreneva2010@yandex.ru.

Valery R. Grosman, Associate Professor, Moscow State Academy for River Transport, branch of Admiral Makarov State University of Maritime and Inland Shipping; Novodanilovskaya nab., 2, k.1, 117105, Moscow, Russia, phone: +7(499)618-52-56;

E-mail: elena.koreneva2010@yandex.ru.
Коренева Елена Борисовна, профессор, доктор технических наук; Московское высшее общевойсковое командное орденов Жукова, Ленина и Октябрьской Революции Краснознаменное училище, 109380, Россия, г. Москва, ул. Головачева, д.2; тел.: +7(499)175-82-45, E-mail: elena.koreneva2010@yandex.ru.

Гросман Валерий Романович, старший преподаватель, Московская государственная академия водного транспорта - филиал Государственного университета морского и речного флота имени адмирала С.О. Макарова; 117105, Россия, г. Москва, Новоданиловская наб., д.2, корп.1, тел.: +7(499)618-52-56;

E-mail: elena.koreneva2010@yandex.ru. 